Available online on 15.3.2018 at http://ujpr.org
Universal Journal of Pharmaceutical Research
An International Peer Reviewed Journal
Open access to Pharmaceutical research is an open access article distributed under the terms of the Creative Commons Attribution-Non
Commercial Share Alike 4.0 License which permits unrestricted non commercial use,
provided the original work is properly cited
Volume 3, Issue 1, 2018

\title{
INVESTIGATING THE RELATION OF TALENT MANAGEMENT WITH DEVELOPING SUCCESSORS OF HUMAN POWER OF KERMAN UNIVERSITY OF MEDICAL SCIENCES

\author{
Abbas Ghavam ${ }^{1}\left(\mathbb{D}\right.$, Neda Molai Hajebi ${ }^{2}$, Jamalledin Alvaani ${ }^{3}(\mathbb{D}$ \\ ${ }^{I}$ Department of Environmental Science, Institute of Sciences and High Technology and Environmental Sciences, Graduate \\ University of Advanced Technology, Kerman, Iran. \\ ${ }^{2}$ Department of Healthcare Management, Marvdasht Branch, Islamic Azad University, Marvdasht, Iran. \\ ${ }^{3}$ Department of Psychology, Marvdasht Branch, Islamic Azad University, Marvdasht, Iran.
}

\section{ABSTRACT}

Objectives: Today, financial and technological resources are not only enumerated the organization advantage but possessing capable and mighty people may also compensate for lack or imperfection of other resources. In the present competitive status, only those organizations will be successful in obtaining preeminent that have comprehended the strategic role of their human resources and have skillful, knowledge- oriented, qualified, elite and capable human resources. This paper was conducted with the aim of investigating the relation of talent management with developing successors of human resources of Kerman University of Medical Sciences.

Methods: The method used in the present study is of correlation type which was conducted using stratified random sampling method in Military University of Medical Sciences. Also, Ahmadi talent management questionnaire (2012) and Kim developing successors (2006) were used. For data analysis, Pearson correlation test, Kolmogorov- Smirnov test was used.

Results: This study showed that there is a significant and positive relation between talent management and developing successors. Also, there is a significant and positive relation between talent management components (personnel selection, personnel participation, personnel training, and personnel maintenance) and developing successors of human power.

Conclusion: Applying talent management is necessary in any organization in all fields. Since human power of an organization, is considered its greatest wealth, therefore, noticing the personnel talent is very significant since the organizations success depends on the capable and mighty personnel.

Keywords: Developing successors, personnel selection, personnel participation, personnel training, personnel maintenance, talent management.

Article Info: Received 16 December 2017; Revised 3 February; Accepted 1 March, Available online 15 March 2018

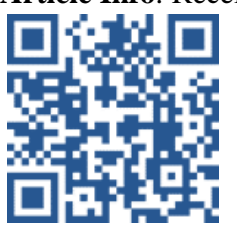

Cite this article-

Ghavam A, Hajebi NM, Alvaani J. Investigating the relation of talent management with developing successors of human power of Kerman University of medical sciences. Universal Journal of Pharmaceutical Research 2018; 3(1): 31-36.

DOI: http://doi.org/10.22270/ujpr.v3i1.R6

Address for Correspondence:

Abbas Ghavam, Department of Environmental Science, Institute of Sciences and High Technology and Environmental Sciences, Graduate University of Advanced Technology, Kerman, Iran. E-mail: ghavam39@gmail.com

\section{INTRODUCTION}

In recent years that the concept of human resources has been replaced with human asset and knowledge development is considered the most important foundation of human civilization, encountering complicated organizational issues required human talent and knowledge more than advanced instruments ${ }^{1,2}$.Undoubtedly, attraction and employment of capable and qualified human power is among necessary issues, but studies show that many organizations encounter problems in this field and don't have required potency in maintaining and keeping their personnel as organizational asset.
Increasing demand of employers for attracting skillful forces in one hand and the personnel tendency to seizing and possessing jobs on the other hand, have formed a battle which should be called talents battle. In this battle, successful organizations try to attract and maintain the talents required for their life continuation utilizing suitable procedures, programs and strategies. For this purpose, organizations should know with which needs are encountered at present and in future to be able to identify the potential talents among their personnel according to them, in other words, to be able to manage talents ${ }^{3,4,5}$. Talent management includes utilizing an integrate series of activities, for securing 
that the organization could attract and breed its required talents at present and future. The goal is assuring the talent circulation in the organization remembering this principle that talent is main and major source of each organization. Clearly, the aim of creating a talent management system is the positive impact on individual and organizational staff. One of factors that differentiate the personnel performance from each other is the individuals ${ }^{6,7,8}$. If for acquiring a skill in an activity, various people stand in similar conditions and situations, we will notice that the existing difference in their performance has been due to the individual internal factors. Human resources in current organizations have a special value; in fact they play the role of strategic assets. Recognizing the personnel abilities and qualifications and managing them for actualizing these capabilities is among serious duties of managers. Experience has shown that the organizations which have noticed their human resources and use talent management have a better performance comparing competitor organizations. Talent management creates this confidence that any of personnel with special skills and talents has stand in suitable job. Moreover, advantages of compensating services are just and even. Also, their job route is clear and acts as an increasing incitation factor for better occupation opportunities. Talents management provides suitable processes and instruments for supporting and empowering managers. In this way, they find out that what expectations they should have from their personnel that this causes improvement of working relationships ${ }^{9}$. As a result, the organization, with investment of talent management in one hand, enjoys return on investment and on the other hand, will have various talents in the organization. In such a condition, the organization benefits from advantages of agile and motivated work force that this, by itself, will lead to organizational efficiency. Ghousi et al., and Vedal et al., in separate studies investigated the role of talent management and concluded that talent management includes consequences like personnel commitment ${ }^{6,7}$. One of instruments of managing talents and supplying elite forces for the organization main occupations is to create a plan called developing successors. Developing successors is a plan during which suitable people are selected for occupying high order and major management posts of an organization among talented and qualified people. In this process, the organization human talents are identified for occupying main posts in the future and gradually get ready through various training plans for undertaking these jobs and responsibilities. The developing successors plan enables the organizations managers and personnel to define operational and functional standards. The organizations, by implementing the system of developing successors could lower force circulation rate, raise the personnel spirit and guide the most qualified people to the organization key posts. The organization performs developing successors plan with various methods and different combinations and complexities in respect of recognizing talents, nurturing skills and relation with other human resources operations.
The U.S national management academy has provided the following definition about developing successors management: developing successors management is wider than merely dealing with a list of candidates who want to be replaced in the specified posts, but is a deep and systematic effort for predicting management requirements, identifying a series of talented and highpotency candidates, developing and nurturing those candidates management qualifications in a planned process, learning and then selecting managers among those series of reserves of high-potency and talented managers. In Karol viewpoint, the concept of developing successors points to a regular process by means of which the individual and professional improvement is matched with strategic plan to make sure that there are ready people with correct attitude and skill for completing any vacant post at proper time. If the organizations wish permanence in a competitive and dynamic environment, many requirements should be considered. One of the most important of them is to occupy important management posts. Thomas et al., in their study concluded that personnel empowerment has a direct, positive and significant impact on breeding talent and developing successors ${ }^{9}$. Personnel empowerment has a significant impact on developing successors. The performed studies during past years have emphasized significance of management and developing successors planning. Studies of Hariri et al., ${ }^{10}$, Bidmeshki et al., ${ }^{11}$, Dian Strofnif et al., ${ }^{12}$ have emphasized the significance of talent management and developing successors by investigating the relation of talent and developing successors. High managers also mention this topic as a main concern. Corn- Free Company through a survey asked managers to evaluate topics that their companies will face in next 5 years. As pioneer companies, they placed management succession after economic issues and strategic planning. Based on the theory of Lester Kouron managers are committed to protect human resources as much as they are committed to loss and profit against shareholders. The performed studies about talent management are mainly towards devising some approaches for optimal use of available resources and specialized knowledge provided for personnel. Talent management in the past has frequently been active in a non-formal state but now is now felt formally in all its required aspects. Since, noticing human resources in Iran doesn't have much record, so talent management subject has less been noticed by managers. Little studies have been performed relating to talent management and developing successors but yet there are many ambiguities in this field which requires performance of many studies in this field. Regarding the expressed issues and also for extending talent management and human forces successors developing, the author decided to investigate a part of these ambiguities and ambiguous points.

\section{METHODS}

The present study is considered among applieddevelopmental studies in respect of objective and the aim of applied studies is to develop knowledge for applying in a special field. This study is descriptive- co 
relational based on method of collecting data. In this method, by investigating current conditions and collecting more suitable and complete data from human society, a full recognition of the society status at present is obtained. In fact, in this method the author collects data about reality and the results obtained from it are interpreted quantitatively. In this study, the variable of talent management is considered as predictor variable and the developing successor variable as criterion variable ${ }^{13,14}$. The statistical population of this study includes all staff personnel of Kerman University of Medical Sciences that were totally 500. The number of statistical sample members which have been obtained using Morgan Table and includes 217 persons. In this study, simple random sampling method has been used. In this study, research data is analyzed in two levels of collecting and using SPSS software. A. in descriptive statistical level, from diagrams, frequency distribution Tables and percent relating to demographic features were used. B. in inferential statistics level, appropriate to data assessment and statistical assumptions, KolmogorovSmirnov test, Pearson correlation factor was used.

\section{RESEARCH TOOLS}

A: Talent management questionnaire: talent management questionnaire was designed by Ahmadi et $a l^{7}$. Talent management questionnaire has 28 items and 4 dimensions as follows: talents attraction system, system of evaluating talents discovery, system of developing talents training and system of preserving talents. Items of this questionnaire are scores as 5option Likert range (quite disagree $=1$ to quite agree $=5$ ). The questionnaire reliability has been obtained through Cronbach's alpha by Ahmadi as 95. In this study the validity has been obtained 85 .

B: The questionnaire of developing successors: has been designed by Kim et al., Human power developing successor's questionnaire has 32 items. The items of this questionnaire are scored as a 5-option Likert range (from quite disagree $=1$ to quite agree $=5$ ). In this study, Cronbach's alpha was obtained $82^{15,16}$.

\section{RESULTS}

Among 209 participants in this study, 149 are men (71\%) and 60 women (28.7). the age range of participants in this study is 35 persons in age group of 20-30 years, 78 persons in age group of 31-40, 69 persons in age group of 41-50, 27 persons in age group of above 51 years old. 21 persons have diploma, 20 persons have associate diploma, 90 persons have bachelor's degree , 65 persons have master's degree and 13 persons have Ph.D. degree. In frequency distribution of job record, 64 persons have record below 10 years, 73 persons between 11-20 years and 72 persons between 20-30 years occupational record.

Regarding data analysis, since talent management variable and developing successors are in the level of distance assessment, so Pearson correlation coefficient was used. Regarding the SPSS output, Pearson correlation coefficient for these two variables has been 0.64 and the significance rate is less than 0.05 which is less than standard significance level $(\alpha=5 \%)$. So, the research hypothesis is confirmed in confidence level $95 \%$, therefore, there is a significance level between two variables ${ }^{17,18}$. In this hypothesis, the determination factor rate $\left(\mathrm{R}^{2}\right)$ has been $41 \%$, in this meaning that talent management has had $41 \%$ of developing successors predicting ability (Table 1).

Table 1: The correlation between talent management with developing successors.

\begin{tabular}{lccc}
\hline $\begin{array}{l}\text { The variable } \\
\text { statistical } \\
\text { index }\end{array}$ & $\begin{array}{c}\text { Correlation } \\
\text { factor }\end{array}$ & $\mathbf{R}^{2}$ & $\begin{array}{c}\text { Significance } \\
\text { level }\end{array}$ \\
\hline $\begin{array}{l}\text { Talent } \\
\text { management }\end{array}$ & $64.3^{* *}$ & $41.3 * *$ & 0.000 \\
$\begin{array}{l}\text { Developing } \\
\text { successors }\end{array}$ & & & \\
\hline & $* * P \leq .01 * P \leq .05$ &
\end{tabular}

In this study, since the variable of selecting talented personnel and developing successors are in distance assessment level, so Pearson correlation coefficient has been used. Regarding the SPSS output, Pearson correlation coefficient for these two variables 0.54 and the observed significance number 0.000 is less than 0.05 ( $\operatorname{sig}>0.05)$ and the standard significance level $(\alpha=$ $5 \%$ ), so the research hypothesis is confirmed in confidence level 0.95 , therefore, there is a significant relation between two variables. In this hypothesis, the determination factor rate $\left(\mathrm{R}^{2}\right)$ has become $29 \%$. In this meaning that talented personnel selection has had 29\% of developing successors predicting ability (Table 2).

Table 2: Correlation rate between after talented personnel selection with developing successors.

\begin{tabular}{lccc}
\hline $\begin{array}{l}\text { The variable } \\
\text { statistical } \\
\text { index }\end{array}$ & $\begin{array}{c}\text { Correlation } \\
\text { factor }\end{array}$ & $\mathbf{R}^{\mathbf{2}}$ & $\begin{array}{c}\text { Significance } \\
\text { level }\end{array}$ \\
\hline $\begin{array}{l}\text { Talent } \\
\text { personnel } \\
\text { selection }\end{array}$ & $54.5 * *$ & $29.7 * *$ & 0.000 \\
$\begin{array}{l}\text { Developing } \\
\text { successors }\end{array}$ & & & \\
\hline & & & \\
\hline
\end{tabular}

Regarding SPSS output, Pearson correlation coefficient for variable of talented personnel participation and developing successors has been 0.62 and the observed significance number rate 0.000 is less than 0.05 that is less than the standard significance level $(\alpha=5 \%)$. So the research hypothesis in confidence level $95 \%$ is confirmed. Therefore, there is a significant relation between two variables. In this hypothesis, the determination coefficient rate $\left(\mathrm{R}^{2}\right)$ is $38 \%$. In this meaning that talented personnel participation is $38 \%$ of the ability of developing successors predicting ability (Table 3).

Table 3: The correlation rate between talented personnel participation and developing successors.

\begin{tabular}{cccc}
\hline $\begin{array}{c}\text { The variable } \\
\text { statistical } \\
\text { index }\end{array}$ & $\begin{array}{c}\text { Correlation } \\
\text { factor }\end{array}$ & $\mathbf{R}^{2}$ & $\begin{array}{c}\text { Significance } \\
\text { level }\end{array}$ \\
\hline $\begin{array}{c}\text { Talent } \\
\text { personnel }\end{array}$ & $62.0^{* *}$ & $38.5^{* *}$ & 0.000 \\
$\begin{array}{c}\text { selection } \\
\text { Developing } \\
\text { successors }\end{array}$ & & & \\
\hline
\end{tabular}


Regarding the following Table, since the variable of talented personnel and developing successors are in distance assessment level; Pearson correlation coefficient has been used. Regarding SPSS output, Pearson correlation coefficient for these two variables has been 0.54 and significance number rate 0.000 is less that 0.05 that is less than standard significant level $(\alpha=5 \%)$, so the research hypothesis is confirmed in significance level of $95 \%$, so there is a significant relation between two variables. In this hypothesis, the determination coefficient rate $\left(\mathrm{R}^{2}\right)$ is $34 \%$. In this meaning that talented personnel training is $34 \%$ of developing successors predicting ability (Table 4).

Table 4: Correlation rate between talented personnel dimension with developing successors.

\begin{tabular}{lccc}
\hline $\begin{array}{l}\text { The variable } \\
\text { statistical } \\
\text { index }\end{array}$ & $\begin{array}{c}\text { Correlation } \\
\text { factor }\end{array}$ & $\mathbf{R}^{2}$ & $\begin{array}{c}\text { Significance } \\
\text { level }\end{array}$ \\
\hline $\begin{array}{l}\text { Talent } \\
\text { personnel } \\
\text { training }\end{array}$ & $58.9^{* *}$ & $34.7^{* *}$ & 0.000 \\
$\begin{array}{l}\text { Developing } \\
\text { successors }\end{array}$ & & & \\
\hline
\end{tabular}

Regarding Table 5, since talented personnel preservation and developing successors are in distance assessment level, and then Pearson correlation coefficient has been used.

\begin{tabular}{|c|c|c|c|}
\hline $\begin{array}{l}\text { The variable } \\
\text { statistical } \\
\text { index }\end{array}$ & $\begin{array}{l}\text { Correlation } \\
\text { factor }\end{array}$ & $\mathbf{R}^{2}$ & $\begin{array}{c}\text { Significance } \\
\text { level }\end{array}$ \\
\hline $\begin{array}{l}\text { Talent } \\
\text { personnel } \\
\text { preservation } \\
\text { Developing } \\
\text { successors }\end{array}$ & $53.5 * *$ & $28.6 * *$ & 0.000 \\
\hline
\end{tabular}

Regarding SPSS output, Pearson correlation coefficient for these two variables have been 0.53 and significance number rate 0.000 is less than 0.05 ( $\mathrm{sig}>0.05$ ) that is less than standard significance level $(\alpha=5 \%)$, so the research hypothesis is confirmed on confidence level $95 \%$. Therefore, there is a significant relation between two variables. In this hypothesis, determination coefficient rate $\left(\mathrm{R}^{2}\right)$ is $38 \%$, it means that talented personnel preservation is $28 \%$ of developing processors predicting ability.

\section{DISCUSSION}

The aim of the present study is to investigate the relation between talent management of human forces of Kerman University of Medical Sciences. Regarding the Table, the first hypothesis showed that there is a significant and positive relation between management style and developing successors. In this hypothesis, determination coefficient rate $\left(\mathrm{R}^{2}\right)$ is $38 \%$. It means that talent management is $41 \%$ of the ability of predicting successor developing. In explaining these results, we can say that when an organization invest on its talents, provides the ground for suitable successor. Since talent management creates this confidence that any personnel with special talent and skill has located in suitable occupation, also their occupational route is clear and act as an increasing incitation factor for better occupational opportunities inside and outside the organization. Talent management creates suitable processes and instruments for supporting and empowering managers. In this way, the find out what they should expect their personnel that this causes improvement of working relations. As a result, the organization with investment on developing successors, on one hand, will achieve managers, with high situational intelligence, that trust their ability and select the best way when deciding about various occupational issues and on the other hand, will have various talents in the organization. In such a condition, the organization will benefit from advantages of motivated work force that possess self-awareness and self-management. The results of this hypothesis are consistent with the studies of Sayadi et al., ${ }^{15}$, Cheraghi et al., ${ }^{16}$, Bidmeshki et al., ${ }^{11}$, Hariri et al., ${ }^{10}$. , Raman et al., ${ }^{17}$, Vedel et al., ${ }^{7}$, Thomas et al., ${ }^{9}$ and Mateso et al., 18. The result of the first secondary hypothesis which had addressed the relation between activities relating to selection of talented personnel with developing successors among personnel of Kerman University of Medical Sciences showed that there is a significant and positive relation between talented personnel and developing successors. In this hypothesis, determination coefficient rate $\left(\mathrm{R}^{2}\right)$ is $29 \%$. It means that selecting talented personnel has had $29 \%$ the ability of predicting successor's development. In explaining these results, we can say that selection is among primary processes and principles that other organizational results are obtained from it. In a clearer expression, it could be said that the more successful the organizations are in selecting talented personnel, create better perspective in personnel in this respect and could provide better successors for key personnel that the organization requires their knowledge and experience. The more the organization attempts for selecting personnel and utilizes suitable strategies for their selection, will be more successful in employing talented people. This hypothesis is consistent with the following studies. Ghousi et al., ${ }^{6}$, Cheraghi et al., ${ }^{16}$, Vedal et al., ${ }^{7}$. In the second hypothesis, the relation between activities relating to talented personnel participation with developing successors among personnel of Kerman University of Medical Sciences was addressed that the results indicated the positive and significant relation between talented personnel participation and developing successors. In this hypothesis, the determination coefficient rate $\left(\mathrm{R}^{2}\right)$ has become $38 \%$. This means that personnel participation has $38 \%$ the ability of predicting successor's development. In explaining these results, we can say that personnel participation in the organization decisions causes more tangibility of responsibilities and also their more cooperation in implementing their assigned duties. According to Bhatnagar et al., study, in effective participation of human resources, observing occupational appropriateness in appointment 
and performance management has a considerable impact and causes reinforcement of internal motivations for personnel ${ }^{19}$. This hypothesis is consistent with the following studies, Tahmasbi et al., Sayadi et al., ${ }^{15}$, Vedal et al., ${ }^{7}$, Harley Hansen and others $^{20}$. The results of Table of third hypothesis based on existence of a relation between talented personnel with developing successors among personnel of Kerman University of Medical Sciences indicates the significant and positive relation between talented personnel training and developing successors, in this hypothesis, determination coefficient rate $\left(\mathrm{R}^{2}\right)$ is $34 \%$. This means that talented personnel training have $34 \%$ the ability of predicting successor's development. In explaining these results, we can say that talented personnel training in the organization is related to providing appropriate successors for key posts. The more the selected elites consider themselves talented and or they are really expert and skillful, they more consider themselves in need of complex and specialized training. According to findings of Berger et al., training and improvement in the organization includes coaching and supervising on job, holding meeting with personnel for current issues, corporative training courses, courses out of the organization, teaching training courses, help from consultant and psychologist and extra activities and since the main aim of training personnel is to obviate performance defects and also improving human resources, this is proportionate to the results of evaluating performance. This hypothesis is consistent with studies of Ghousi et al., ${ }^{6}$, Palangi et al., ${ }^{21}$, Hosseinpour et al., ${ }^{22}$.

The results of the fourth hypothesis confirm the relation between maintaining talented personnel with developing successors among personnel of Kerman University of Medical Sciences. There is a positive and significant relation between talented personnel maintenance and developing successors. In this hypothesis, determination coefficient rate $\left(\mathrm{R}^{2}\right)$ is $28 \%$. This means that preserving and maintaining talented personnel $28 \%$ has the ability of predicting successor's development ${ }^{24}$. In explaining these results, we can say that talent preservation and implementing strategies for preventing from personnel desertion is one of principles of accurate management of the organization talents. If an organization wants to manage its talents and elites well, besides creating financial motives, it should notice other motivational and encouraging factors for their preservation, since elite people are not readily replaceable in respect of expertise and experience and passing the process of finding suitable successor leads to imposing extra costs on the organization. Findings of Sayadi et al., ${ }^{15}$, Moghli et al., and Yadollahi et al., ${ }^{23}$, Hosseini et al., ${ }^{22}$ are consistent with the results of the present study.

\section{CONCLUSION}

Applying talent management in all fields including seeking talent, knowing talent, assessing talent, selecting talent, assigning talent and keeping talent are necessary in any organization. Since human resources are considered the organization's greatest wealth, so noticing personnel talent is very significant, since the organizations success depends on talented and mighty personnel. Therefore, applying talent management provides personnel and is effective in their effectiveness and following that the organization will achieve its objectives. In any case, lack of talent management system, will encounter the organizations with great financial and non-financial loss. One of these losses is lack of suitable successor. Lack of successor's development in the organization creates direct and indirect costs for the organization. Some of direct costs of developing successors are finding new employees, the process of selecting, employing and training. On the other hand, indirect costs of selecting suitable successors include job leaving unoccupied, pressure on other personnel, reduction of work quality, and reduction of the organization phase, learning costs and losing organizational experience or organizational memory. For this reason, noticing personnel talent is important. Talent management plays role in preserving and maintaining talented human resources. In this era which is called era of knowledgeable personnel, the organizations compete based on their personnel talent and skill and by maintaining the most talented personnel, the best means of securing the competitive advantage is created that in this case, the organization obtains the advantages of motivated and agile personnel.

Regarding that talent management believes that talented people play a principal role in the organization success, this could have an important role in maintaining the success of talented human resources by facilitating occupational route advancement and effective implementation of talent management strategy and also selecting and making talented personnel ready for key posts. Keeping personnel has a very close link with management system of the organization performance. Noticing challenges and expectations of these people is very significant for their maintenance, that in this regard, codifying a kind of meritocracy is one of main approaches.

\section{AUTHOR'S CONTRIBUTION}

The manuscript was carried out, written, and approved in collaboration with all authors.

\section{ACKNOWLEDGEMENTS}

The authors extend their thanks and appreciation to the Department of Environmental Science, Institute of Sciences and High Technology and Environmental Sciences, Graduate University of Advanced Technology, Kerman, Iran to provide necessary facilities for this work.

\section{CONFLICT OF INTEREST}

No conflict of interest associated with this work.

\section{REFERENCES}

1. Zeinedding B, Zohreh A, FaribaV, Mozhdeh. Comparing current status of developing successors and talent management with their optimal status in high education system. Research and Planning J High Educ 2014; 72.

2. Gay Mand Sims D. Building tomorrows talent, Translated by Jazany N, Tehran: Sarmand publication, 2009. 
3. Sarafizadeh A, Ali A. Management information systems, theories, concepts and applications, Tehran, Masir publications 2002.

https://doi.org/10.1080/00207720410001734183

4. Al Ariss A, Cascio WF, Paauwe J. Talent management: Current theories and future research directions. J Business 2014; 49(2):173-9.

https://doi.org/10.1016/j.jwb.2013.11.001

5. Daftari M. Investigating the relation between talent management and working motivation with individual motivation among teachers and principals of high schools of Khoramabad City, Master's thesis, Alameh Tabatabie University, 2016.

https://doi.org/10.2991/icetep-18.2019.19

6. Ghousi S, Mehrara A, Shakeri, Gholamreza. Talent management role in maintaining and keeping talented human resources in national company of distributing oil products of Sari region. Scientific J 2015; 52. https://doi.org/10.1257/jep.30.4.83

7. Vedel I, Lapointe L, Lussier MT, Richard C, Goudreau J, Lalonde L, Turcotte A. Healthcare professionals' adoption and use of a clinical information system (CIS) in primary care: Insights from the Da Vinci study. I J med inform 2012; 81(2):73-87. https://doi.org/10.1016/j.ijmedinf.2011.11.002

8. Latifi M, Abdolhossinzadeh M, Azarfar A. Designing the pattern of developing successors in governmental organizations through application of structuralinterpretive modeling. Scient Res J Gov Org 2016; 22:431-48.

9. Thomas KW, Velthouse BA. Cognitive elements of empowerment: An "interpretive" model of intrinsic task motivation. Academy Manag Rev 2012; 15(4):666-81 https://doi.org/10.5465/amr.1990.4310926

10. Hariri N, Tabrizi N. Talent management and developing successors in libraries, case study: branches of Islamic Azad University, Daneshshenasi J 2016; 9(29): 20.

11. Bidmeshki Z, Adli Fariba. Comparing current status of developing successors and talent management with its optimal status in high education system, research and planning in high education journal 2014; 72 : 25.

12. Diane O, Neefe. Succession Planning in a Two-Year Technical College System. A dissertation: submitted to the faculty of the graduate school of the University of Minnesota 2015.

13. Ebrahimi M, Fahimeh A, Moharami A. Investigating the impact of seeking talent management on developing successors, case study: managers of Mohaghegh Ardabili University 2016; (43):12.
14. Ali B, Nasrin R, Kamran N. Investigating and analyzing the relation of talent management with NAJA personnel performance. Scientific Prom J 2015; (29): 10.

15. Saied S, Mohammadi M. The relation between talent management and personnel job satisfaction in central staff of social security fund, development management process 2012; (2): 25

16. Cheraghi N. Investigating the impact of talent management on information technology management, master's hypothesis, Allameh Tabatabie University 2014.

17. Raman R, Chadee D, Roxas B, Michailova S. Effects of partnership quality, talent management, and global mindset on performance of offshore IT service providers in India. J Int Manag 2013; 19(4): 333-46. https://doi.org/10.1016/j.intman.2013.03.010

18. Mateso PE. Understanding succession planning and management efforts at Midwestern University: A mixed methods study (Doctoral dissertation, Bowling Green State University). 62-Cheryl L, Richards. A new paradigm: strategies for succession planning in higher education, Capella University, 2009.

19. Bhatnagar J. Talent management strategy of employee engagement in Indian ITES employees: key to retention. Employee Relations 2007; 29(6):640-63. https://doi.org/10.1108/01425450710826122

20. Hurley-Hanson AE, Giannantonio CM, Carlos H, Harnett J, Jetta M, Mercier M. Crisis response plans, crisis communication plans, and succession planning: The effects of 9/11 on human resource preparedness. In Allied Academies International Conference. Academy of Strategic Management. Proceedings Jordan Whitney Enterprises, Inc.64. 2008; 7(1): 29 https://doi.org/10.1023/B:ERRJ.0000017518.06989.85

21. Palangi A. Investigating the relation between talent management and developing sucessors in Refah bank, master's thesis, Payam Noor University, south branch, 2011

22. Hossein P, Davoud, M, Manoucher M, Mohammadi S. Investigating the role of talent management in developing the organization intellectual asset 2015; (3):4.

23. Moghli A, Sahar Y. Investigating the talent management system impact on developing successors in governmental organizations of Shiraz City, third national congress of accounting and management. Tehran, Narkish information institute, 2014.

24. Hosseini A. Investigating the talent management role in supplying and maintaining human resources, international economy and experiences 2011; (23): 6 . 